\title{
Subjective Health Complaints in Fifteen-Year-Old Czech Adolescents: The Role of Self-Esteem, Interparental Conflict, and Gender
}

\author{
Petra Daňsová, Ondřej Bouša, \\ Lenka Lacinová, Petr Macek, Hynek Cígler \\ Institute for Research on Children, Youth and \\ Family, Faculty of Social Studies, \\ Masaryk University, Czech Republic
}

\author{
Zuzana Tomášková \\ Department of Psychology, Faculty of \\ Social Studies, Masaryk University, \\ Czech Republic
}

\begin{abstract}
This cross-sectional study aims to 1) investigate the factor structure and measurement invariance of subjective health complaints inventory in terms of gender, 2) examine the role of selfesteem, interparental conflict and gender in Czech adolescents' subjective health complaints, and 3) examine a possible moderating effect of gender in these relationships. Czech adolescents $(N=1602,51 \%$ girls $)$ from an epidemiological part of the European Longitudinal Study of Pregnancy and Childhood (ELSPAC) completed questionnaires at home and a psychological sub-sample of ELSPAC ( $n=343,46 \%$ girls $)$ completed questionnaires during individual psychological examinations in the years 2006 and 2007. The subjective health complaints inventory used in this study is a unidimensional and scalar invariant for sex. Girls reported more subjective health symptoms than boys. Self-esteem may play a protective role for the adolescents' subjective health symptoms, especially in boys, whereas self-blame and threat in an interparental conflict may serve as a risk factor similarly for both sexes.
\end{abstract}

Key words: subjective health complaints, self-esteem, interparental conflict, Czech adolescents

\section{Introduction}

Subjective health complaints are symptoms that an individual feels on an almost everyday basis with or without any specific medical diagnosis. These include subjective physical health

\section{Acknowledgements}

We appreciate the adolescents who participated in our research. We also thank Radim Lacina for his valuable comments and help. This work was financially supported by the RECETOX RI project CZ.02.1.01/0.0/0.0/16 013/0001761.

Correspondence concerning this article should be addressed to Dr. Petra Daňsová, Institute for Research on Children, Youth and Family, Faculty of Social Studies, Masaryk University, Joštova 10,602 00, Brno, Czech Republic. E-mail: dansova@fss.muni.cz

Received January 25, 2019 complaints such as headache, backache, muscle or bone pain, gastrointestinal pain, colds, allergies, as well as psychological complaints or pseudo-neurological disorders, such as fatigue, malaise, anxiety, and depression, sleeping problems, reddening of skin or heart palpitations (Haugland, Wold, Stevenson, Aaroe, \& Woynarowska, 2001). A question remains whether these complaints are better empirically reflected by being divided into psychological and somatic symptoms (e.g., Haugland et al., 2001; Hetland, Torsheim, \& Aarø, 2002) or by a shared common factor of subjective health complaints (e.g., Takata \& Sakata, 2004).

Some studies have labelled these complaints as psychosomatic (e.g., Kinnunen, Laukkanen, \& Kylmä, 2010) or somatic complaints (Torsheim $\&$ Wold, 2001). However, it is to be noted that despite the use of different terms for the concept being measured (psychosomatic, somatic, or subjective health complaints), the frequently 
used measuring tools are very similar to each other, including identical items for particular complaints. In psychosomatic complaints, there is an underlying assumption about the cause of these complaints - i.e., that the person has no medical diagnosis. This is usually not reflected in the studies that have called these complaints psychosomatic. On the other hand, in cases of somatic or subjective health complaints, there is no assumption about the etiology and the term is only descriptive (Torsheim \& Wold, 2001). Therefore, we chose to use the term subjective health complaints in our study.

Subjective health complaints have personal and economic impacts and are associated with health care utilization in adults and adolescence (e.g., Belmaker, Espinoza, \& Pogrund, 1985; Fink, Sørensen, Engberg, Holm, \& Munk-Jørgensen, 1999). Subjective health complaints are common among adolescents with an increasing occurrence from childhood to adulthood (Berntsson \& Köhler, 2001; Haugland et al., 2001). It has been repeatedly confirmed that these subjective health complaints are negatively related to the lives of adolescents in many aspects; these include a reduction in daily activities, school absence, eating disorders, inability to meet friends and to pursue hobbies, etc. (Torsheim \& Wold, 2001; Roth-Isigkeit, Thyen, Stöven, Schwarzenberger, \& Schmucker, 2005). It was also found that adolescents with multiple health complaints exhibit more somatization and anxiety symptoms in early adulthood (Kinnunen, Laukkanen, \& Kylmä, 2010) and are at an increased risk of chronic pain in adulthood (Jones, Silman, Power, \& Macfarlane, 2007).

The occurrence of subjective health complaints in adolescence is well documented in European and North American samples. The most common somatic and psychological symptoms in adolescents from Finnish, Scottish or US samples are headache, stomach ache, back pain, morning fatigue, nervousness, irritability, difficulty sleeping and depression (e.g.,
Ghandour, Overpeck, Huang, Kogan, \& Scheidt, 2004; Kinnunen, Laukkanen, \& Kylmä, 2010; Sweeting \& West, 2003). In recent years, findings have also been reported from Central European countries. A study by Gecková et al. (2001) found that in Slovak adolescents, the most frequent physical health complaints are headaches and back pain, which is comparable to other Western European countries. In the Health Behaviour in School-aged Children Study (HBSC; Inchley et al., 2016), results from the Czech Republic show that among 15-yearold adolescents, frequent health symptoms include feeling nervous, sleep difficulties, feeling low or headache. In total, $48 \%$ of girls and $28 \%$ of boys suffer from multiple health complaints more than once a week.

According to previous studies, girls reported more symptoms compared to boys and the prevalence of symptoms increased with age (e.g., Hetland, Torsheim, \& Aarø, 2002; Inchley et al., 2016; Ravens-Sieberer et al., 2009). These results have also been reported in Czech adolescents (Inchley et al., 2016; Osecká, Macek, \& Řehulková, 1999). The reasons for the difference in occurrence between girls and boys probably lie in biological, social and psychological factors. For girls, it is more socially acceptable to report symptoms than for boys due to the process of gender socialization (Ruble \& Martin, 1998). Adolescent girls are more focused on their own body and on bodily changes than boys (Strandbu \& Kvalem, 2014). In addition, biological factors play a role because of different pubertal bodily changes in girls and boys (Aro\& Taipale, 1987).

\section{Subjective Health Complaints, Interparental Conflict, and Self-Esteem in Adolescence}

Subjective health complaints are associated with environmental factors such as school-related stress (Torsheim \& Wold, 2001) or familyrelated stress (Repetti, Taylor, \& Seeman, 2002; 
Ghandour et al., 2004). It was repeatedly found that interparental conflicts, being an inevitable characteristic of family relations, adverselyaffect child and adolescent health, and represents one of the most stressful events in the children's lives (Cummings \& Davies, 2002). Låftman and Östberg (2006) found that the quality of social relationships with parents and peers as perceived by a cross-sectional Swedish sample of 10- to 18-year-olds $(n=5137)$ is connected with their health complaints. Michael, Torres, and Seemann (2007) confirmed that a high family conflicthad a negative impact on health habits, resulting in e.g., less sleep and lowered well-being in late adolescents. Higher anxiety, depressive and somatic symptoms were reported by early adolescents from families with a higher conflict between parents(Mechanic \&Hansell, 1989).

Interparental conflict and its subjective perception and evaluation by children and especially by adolescents affects the domain of selfrelated characteristics such as self-esteem. Selfesteem can be characterized as the global subjective evaluation of how individuals feel about themselves. It is related to an individual's general feelings of worth and competence and implies being aware of one's value and overall self-satisfaction (Alsaker \& Kroger, 2006). Amato and Afifi (2006) documented negative relations between interparental conflict, selfesteem, and well-being. In early adolescents (aged 11 to 14 years), higher levels of family conflict were found to be related to lower selfesteem (Shelton \& Harold, 2007). In a study by Macek, Bouša, Vančura, Sokoliová, and Neusar (2011), adolescents with slightly decreasing selfesteem (over the period from 13 to 19), and adolescents with permanently low self-esteem demonstrate lower trust and higher alienation in relationships with parents, a higher frequency of problems with parents, and higher self-blame for interparental conflicts.

In recent years, researchers have been increasingly pointing out a link between self-es- teem and the mental and physical aspects of adolescent health (Byrne, 2000; Erol \& Orth, 2011; Piko, Varga, \& Mellor, 2016). Erol and Orth (2011) found a positive relationship between self-esteem and physical health in adolescence, where adolescents with higher self-esteem showed better health. In particular, it has been shown that the higher the self-esteem, the lower the number of somatic complaints such as abdominal (stomach) pain and malaise (Robinson, Mitchell, Kirkeby, \& Meier, 2006) and depression and anxiety (Byrne, 2000; De Jong, Sportel, De Hullu, \& Nauta, 2012). According to Piko et al. (2016), self-esteem has been found to provide protection against stress and it is related to lower levels of psychosomatic symptoms and mental health problems in both sexes.

Some authors suggest possible gender differences in self-esteem and perception of family conflict, and consequently, a different impact on various outcomes in adolescents' development (e.g., David \& Murphy, 2004; Josephs, Markus, \& Tafarodi, 1992). It has been found that females are more aware of and sensitive to interparental conflict consequences than males, whereas males are more focused on themselves and their own agency compared to females in the context of interparental conflicts (David \& Murphy, 2004; Davies \& Lindsay, 2001; Davies, Myers, Cummings, \& Heindel, 1999). Therefore, adolescent girls may be more reactive on interparental conflict than boys because they are more concerned about the maintenance of interpersonal relationships, while being more aware of the impact of conflict on the whole family, including themselves. These differences may lie also in different gender socialization that may cause different perceptions of the importance of relationships in the family in general (Ruble \& Martin, 1998). It is also assumed that for females, the quality of relationships is more relevant for the feeling of their self-esteem compared to males for whom the quality of relationships may be less essential. 
Males are assumed to have more autonomous or individualistic self-schema compared to females. Because of these differences in self-definitions, some authors suggest that males and females may have different correlates of selfesteem as a result of different gender socialization (Josephs, Markus, \& Tafarodi, 1992). Feeling good about themselves may be more important for boys than for girls and therefore it can be assumed that the impact of low self-esteem on health may be stronger for boys, as well.

A better understanding of factors that may be positively associated with the perception of subjective health complaints is needed. Therefore, the main aim of this study was threefold: 1) to examine the factor structure and measurement invariance for gender of the subjective health complaints scale used in this study; 2) to examine the relationship between perceived interparental conflicts, self-esteem, and subjective health complaints in a sample of 15-yearold Czech adolescents; and 3) to examine gender as a moderator of these relationships. We supposed that higher levels of perceived conflicts and lower self-esteem contributed to a higher level of subjective health complaints of adolescents. Next, we expected that gender could moderate the relationship between the variables. We supposed that in girls, the association between perceived interparental conflict and subjective health complaints would be stronger than in boys. On the other hand, we supposed that in boys, the association between self-esteem and subjective health complaints would be stronger than in girls.

\section{Method}

\section{Research Sample}

To achieve objective 1 , secondary analysis of the data from the epidemiological study ELSPAC (European Longitudinal Study of Pregnancy and Childhood; for details, see Piler et al., 2017) was used; to reach aims 2 and 3, we analyzed the data from respondents participating simultaneously in an additional psychological part of this study (for details, see Ježek, Lacinová, Širůček, \& Michalčáková, 2008). Informed consent was obtained from all individual participants included in the study.

The ELSPAC is a longitudinal epidemiological study that was conducted in five countries including the Czech Republic. All the families of children domiciled and born between March 1991 and June 1992 in medical institutions in the city of Brno and in the town of Znojmo were recruited. The Brno original sample included 5549 families, of which 3859 families had been surveyed following the prenatal period (Ježek, Lacinová, Širůček, \& Michalčáková, 2008). Data used in this study were collected in 2006 and 2007 when the children reached 15 years of age. The sets of questionnaires for parents and children were distributed to the families via post approximately one day after the children's birthdays. The collection of psychological data through individual psychological examinations was conducted from 1999 to 2000 at the children's age of 8 on a quasi-randomly selected subsample of 883 children and their parents. At the age of 15 , a total number of 554 adolescents took part, with 343 (62\%) of them completing questionnaires in both the epidemiological and the psychological part of the study. In all age groups, the individual examination was quite long-lasting, about 2 hours (Ježek et al., 2008).

The "epidemiological sample" under our investigation was composed of 1602 fifteen-yearold adolescents (mean age $=15.38, S D=0.35$; $51 \%$ girls) from the Czech city of Brno (400 000 inhabitants). Regarding family structure, $80.9 \%$ of participants reported that they were living with both parents; $5.5 \%$ with one parent only and $13.6 \%$ with one parent and a stepparent.

The "psychological sub-sample" was composed of 343 fifteen-year-old adolescents (mean age $=15.36, S D=0.34 ; 46 \%$ girls $)$, who also 
participated in the epidemiological part of the study. Regarding family structure, $85.3 \%$ of participants reported that they were living with both parents; $4.7 \%$ with one parent only and $10.0 \%$ with one parent and a stepparent.

According to sub-sample selection, the psychological sub-sample did not differ from the epidemiological sample in terms of subjective health complaints $(t(1604)=-1.39, p=.16, d=$ $0.08)$, gender $\left(\chi^{2}(1)=3.86, p=.05, \varnothing=.05\right)$, age $(t(1550)=1.00, p=.32, d=0.06)$ or family structure $\left(\chi^{2}(2)=6.16, p=.05, \varnothing_{c}=.04\right)$. Although some of these results are at the border of statistical significance, differences between both samples are only small.

\section{Measures}

\section{Subjective Health Complaints}

Subjective health complaints were measured by 15 items designed for the ELSPAC. Each item was aimed at a self-reported health symptom (indeterminate anxiety, unjustified fear, pessimism, inflammability, difficulty sleeping, nausea, intestinal problems, headaches, pain in the neck, long-lasting fatigue, loss of appetite, excessive sweet craving, states of malady, unpleasant feelings as if in a dream, intrusive thoughts); adolescent respondents were asked whether they had experienced any of these symptoms and if so, how often since they turned 11. Responses were measured on a 4-point Likert scale ranging from 0 (never) to 3 (often). The item "excessive sweet craving" was removed from the scale due to both low factor loading of this item and its poor content validity for the health complaints scale in adolescence. The total score was computed as a sum of 14 items. In the present sample, Cronbach alpha is .88 in the epidemiological dataset and .86 in the psychological dataset. This scale was included in the larger set of questionnaires sent to the families during the epidemiological data gathering and was filled out by the adolescents at their homes in pen and paper form.

\section{Interparental Conflict Appraisal}

The Children's Perceptions of Interparental Conflict Scale (CPIC) is an instrument for measuring important dimensions of the interparental conflict from the child's perspective in 51 items (Grych, Seid, \& Fincham, 1992). The CPIC was developed to assess the objective characteristics of the conflict (frequency, intensity, and resolution - subscale conflict properties), as well as the adolescent's subjective evaluation of the conflict (subscales threat and self-blame). This evaluation includes the level of threat perceived by the adolescent when exposed to a conflict, and also the evaluation of his/her coping abilities in such context, how uneasy he/ she feels about the conflict and to what extent he/she feels to be involved in the conflict, and finally, if he/she feels responsible for the conflict of his/her parents. The Czech shortened version (Lacinová, Michalčáková, \& Ježek, 2009) includes 34 items in three subscales as in the original Grych et al.'s study (conflict properties: 13 items, e.g. "I often saw my parents fighting", "When my parents have an argument they yell a lot", Cronbach's alpha = .93; threat: 14 items, e.g. "When my parents argue I worry about what will happen to me", Cronbach's alpha $=.77$; self-blame: 7 items, e.g. "Even if they don't say it, I know I'm to blame for my parents'arguing", Cronbach's alpha $=.80$ ). The participants evaluate each statement on a threepoint scale as true, partly true, or not true. The Czech CPIC has good psychometric properties and was found to be suitable for research purposes (Lacinová, Michalčáková, \& Ježek, 2009).

\section{Self-Esteem}

The 10-item Rosenberg Self-Esteem Scale (RSES) was used (Rosenberg, 1979). The Czech 
translation of this scale was repeatedly used in the ELSPAC (e.g., Macek et al., 2011) and other studies (e.g., Osecká \& Blatný, 1997). Responses were measured on a 4-point Likert format ranging from 1 (strongly disagree) to 4 (strongly agree). Cronbach's alpha of the RSES was .86.

Interparental conflict appraisal and self-esteem measures were filled out by the adolescents in pen and paper form during individual psychological examinations. The average time difference between measuring these variables and measuring subjective health complaints in the epidemiological part of the study was about 3 months.

\section{Data Analysis}

An ordinal multiple-groups confirmatory factor analysis with a robust WLSMV estimator (mean-and variance-adjusted weighted least squares) and delta parametrization was performed in Mplus version 7.2 to assess measurement invariance of the subjective health complaints inventory for gender. In model 1 we tested a one-factor solution regardless of gender; in models 2, 3, and 4 we tested configural (same factor structure), metric (same factor loadings), and scalar invariance (same intercepts and thresholds), respectively. The differences between models were tested by chi-square difference test adjusted for WLSMV estimator (DIFFTEST function in Mplus). As the sensitivity of chi-square difference is too high and increases with the sample size (e.g., Brannic, 1995), we also used difference fit indices according to Chen's (2007) recommendation. The residuals of the items 'nausea' and 'intestinal problems' were allowed to correlate due to the probable similarity in the meaning of the items for adolescents.

The differences between study variables in girls and boys were tested using $t$-test. A hierarchical regression analysis with CFA derived factor score of the subjective health complaints inventory as a dependent variable and gender, self-esteem, conflict properties, threat, and selfblame as independent variables were conducted. In the second step of the analysis, interaction terms for all predictors with gender were included to assess possible moderator effects of gender. Due to the inclusion of interaction terms, all variables were standardized to $z$-scores before the analysis. The assumptions of the regression analysis were checked before the analysis and these assumptions were met.

\section{Results}

Subjective Health Complaints Inventory: Factor Structure and Gender Invariance ("epidemiological sample”)

Confirmatory factor analysis revealed that configural, metric and scalar models provide an acceptable fit to the data (see Table 1). The metric model did not significantly degrade the fit relative to the configural model $\left(\chi_{\text {diff }}^{2}(13)=19.543\right.$, $p=.107)$, both the chi-square test and the other fit indexes provided support for metric invariance. The scalar model resulted in significant degradation of the fit relative to the metric model $\left(\chi_{\text {diff }}^{2}(27)=98.096, p<.000\right)$. Changes in RMSEA and CFI indexes were small and below the cutoffs recommended by Chen (2007). Suggested modification indexes for the model were also small and therefore we considered the scale as a scalar invariant for girls and boys.

Subjective Health Complaints, Self-Esteem and Interparental Conflict ("psychological sub-sample”)

Descriptive statistics and correlations of study variables are presented in Table 2. According to our results, girls reported a higher level of subjective health complaints $(t(341)=$ $-5.715, p<.001, d=0.62)$ and had a higher score 
Table 1 Fit indexes for tested models

\begin{tabular}{lccccccc}
\hline Model & $N$ & $\chi^{2}$ & \multicolumn{1}{c}{$d f$} & \multicolumn{1}{c}{$p$} & \multicolumn{1}{c}{ CFI } & RMSEA & WRMR \\
\hline Model 1 - total & 1602 & 770.86 & 76 & .000 & .951 & .075 & 1.944 \\
Model 2 - configural & 1602 & 863.47 & 152 & .000 & .945 & .076 & 2.095 \\
Model 3 - metric & 1602 & 685.00 & 165 & .000 & .960 & .063 & 2.175 \\
Model 4 - scalar & 1602 & 853.41 & 192 & .000 & .949 & .065 & 2.304 \\
\hline
\end{tabular}

Note. $d f$ - degrees of freedom; CFI - comparative fit index; RMSEA - root mean square error of approximation, WRMR - weighted root-mean-square residual.

Table 2 Descriptive statistics and correlations of study variables for girls and boys

\begin{tabular}{lccccccc}
\hline & Girls & Boys & 1. & 2. & 3. & 4. & 5. \\
\hline 1. Subjective health & $M(S D)$ & $M(S D)$ & & & & \\
complaints & $16.44(7.19)$ & $12.11(6.85)$ & & $-.517^{* *}$ & $.150^{*}$ & $.249^{* *}$ & .102 \\
2. Self-esteem & $2.88(0.49)$ & $3.04(0.45)$ & $-.399^{* *}$ & & $-.212^{* *}$ & $-.260^{* *}$ & $-.149^{*}$ \\
3. Conflict properties & $1.64(0.47)$ & $1.53(0.44)$ & $.173^{*}$ & $-.241^{* *}$ & & $.458^{* *}$ & $.221^{* *}$ \\
4. Threat & $1.61(0.33)$ & $1.55(0.30)$ & $.271^{* *}$ & $-.173^{*}$ & $.554^{* *}$ & & .104 \\
5. Self-blame & $1.17(0.29)$ & $1.22(0.28)$ & $.276^{* *}$ & -.109 & .071 & $.207^{* *}$ & \\
\hline
\end{tabular}

Note. Correlations of study variables for girls are below diagonal, for boys above diagonal.

in conflict properties than boys $(t(340)=-2.226$, $p=.027, d=0.24)$. Boys reported higher selfesteem than girls $(t(341)=3.119, p=.002, d=$ $0.34)$. In the threat and self-blame scale of the interparental conflict there was no difference between girls and boys (threat: $t(340)=-1.865$, $p=.063, d=0.20$; self-blame: $t(341)=1.529, p=$ $.127, d=0.17)$. Age did not differ between girls and boys $(t(326)=0.816, p=.42, d=0.09)$ and also did not correlate with any study variable (subjective health complaints: $r=-.037, n s$; selfesteem: $r=.075, n s$; conflict properties: $r=.043$, $n s$; threat: $r=.051, n s$; self-blame: $r=.145, n s)$. Therefore, age was not entered into the regression analysis.

In the first step of the hierarchical regression analysis, gender, self-esteem, conflict properties, threat and self-blame accounts for $31.8 \%$ of the variation in subjective health complaints
$(F(5,341)=31.35, p<.001)$. Adding interaction terms increased explained variation in subjective health complaints to $33.0 \%$; this change in $R^{2}$ was not significant $(F(4,332)=1.51, p=$ $.20)$.

Table 3 shows that as self-esteem increased, the level of subjective health complaints decreased $(b=-0.37, p<.001)$. Conflict properties were not significantly associated with the level of subjective health complaints $(b=-0.03, p=$ .49). As threat and self-blame increased, the level of subjective health complaints also increased ( $b=0.14, p=.01 ; b=0.10, p=.02$, respectively).

Except for the interaction term for self-esteem, all interaction terms were nonsignificant, which means that gender did not moderate the relationships between conflict properties, threat and self-blame and subjective health complaints. In the case of self-esteem, there was a 
significant interaction term with gender $(b=$ $0.18, p=.048)$. This means that in boys, as selfesteem increased by one unit, the level of health complaints decreased by 0.46 unit, and in girls, this relationship was also negative, but weaker in magnitude - one unit increase in self-esteem meant 0.28 unit decrease in health complaints (see Figure 1).

Table 3 Linear regression models of predictors of subjective health complaints

\begin{tabular}{lcccccc}
\hline & \multicolumn{3}{c}{ Step 1} & \multicolumn{2}{c}{ Step 2} \\
\cline { 2 - 7 } Variable & $B$ & $S E B$ & $95 \%$ CI & $B$ & $S E B$ & $95 \%$ CI \\
\hline (Constant) & $-0.15^{* *}$ & 0.06 & {$[-0.27 ;-0.04]$} & $-0.14 *$ & 0.06 & {$[-0.25 ;-0.02]$} \\
Gender $(1=$ female) & $0.47 * *$ & 0.09 & {$[0.30 ; 0.64]$} & $0.47 * *$ & 0.09 & {$[0.30 ; 0.64]$} \\
Self-esteem & $-0.37 * *$ & 0.04 & {$[-0.46 ;-0.28]$} & $-0.46 * *$ & 0.06 & {$[-0.59 ;-0.34]$} \\
Conflict properties & -0.03 & 0.05 & {$[-0.13 ; 0.06]$} & -0.02 & 0.07 & {$[-0.16 ; 0.11]$} \\
Threat & $0.14 * *$ & 0.05 & {$[0.04 ; 0.24]$} & 0.10 & 0.07 & {$[-0.03 ; 0.24]$} \\
Self-blame & $0.10 *$ & 0.04 & {$[0.01 ; 0.18]$} & 0.03 & 0.06 & {$[-0.09 ; 0.15]$} \\
Self-esteem*Gender & & & & $0.18 *$ & 0.09 & {$[0.00 ; 0.35]$} \\
Conflict properties*Gender & & & & 0.00 & 0.10 & {$[-0.19 ; 0.20]$} \\
Threat*Gender & & & & 0.04 & 0.10 & {$[-0.15 ; 0.24]$} \\
Self-blame*Gender & & & & 0.14 & 0.09 & {$[-0.03 ; 0.31]$} \\
\hline
\end{tabular}

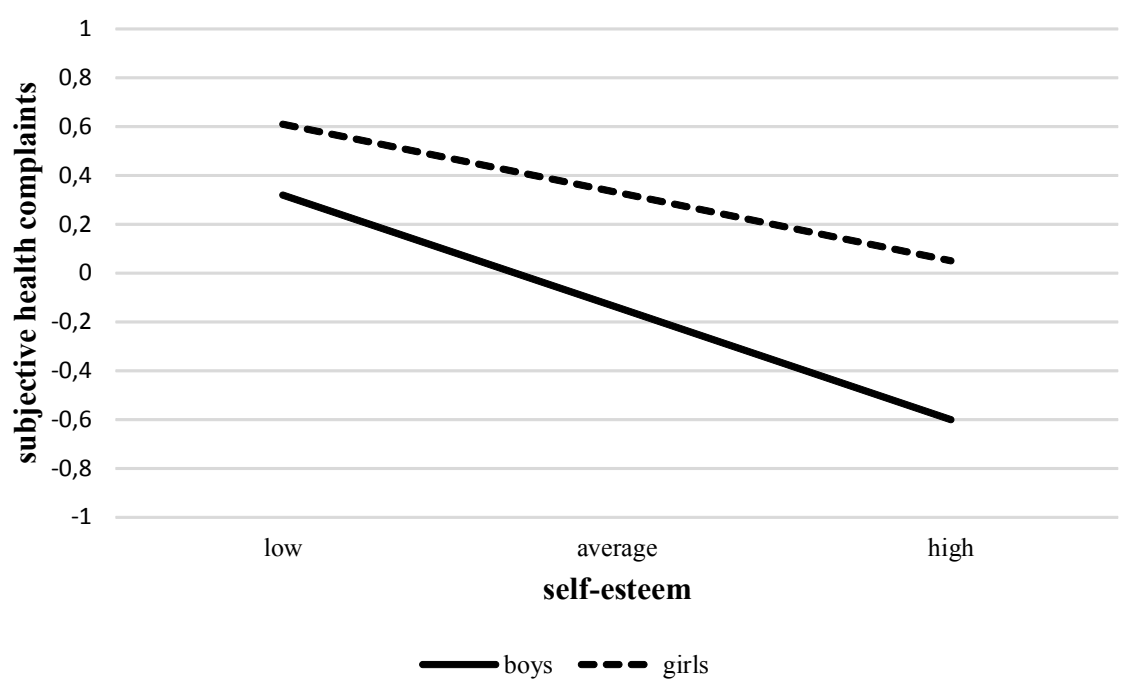

Figure 1 Interaction plot for subjective health complaints and self-esteem by gender 


\section{Discussion}

Our study was primarily focused on subjective health complaints in a sample of 15-yearold Czech adolescents from the ELSPAC and also on examination of relationships between subjective health complaints, self-esteem, and interparental conflict in a smaller subsample of adolescents from the psychological part of the ELSPAC.

The first aim of our study was to examine the factor structure and measurement invariance of the subjective health complaint inventory for gender. This was a necessary step for group comparison because if the scale did not measure the same construct in the same way, the comparisons across groups would not be valid. Subjective health complaints were measured by the inventory designed for the ELSPAC including somatic as well as psychological health complaints (e.g., indeterminate anxiety, pessimism, inflammability, difficulty sleeping, nausea, intestinal problems, headaches). According to our analysis, the inventory used in the current study for measuring subjective health complaints in adolescence is unidimensional, which is similar to the results of Takata and Sakata (2004) and is invariant for gender.

Girls reported a higher level of subjective health complaints compared to boys. Higher occurrence of subjective health complaints in girls has been reported in many previous studies including an earlier study from the Czech Republic (Osecká et al., 1999; Hetland et al., 2002; Inchley et al., 2016; Ravens-Sieberer et al., 2009). There are more possible explanations for these sex differences. First, it is possible that girls are more willing to report health complaints than boys due to the process of gender socialization (Ruble \& Martin, 1998). Second, the biological changes in adolescence are different for girls and boys and it is possible that many complaints are associated with the occurrence of menstrual cycles and the related pain in girls (Aro \& Taipale, 1987). Third, adolescent girls may be more focused on their own body and bodily changes than boys (Strandbu \& Kvalem, 2014). Therefore, it is possible that girls actually experienced more symptoms than boys did, but it is also possible that girls are more focused on these symptoms and are more open in symptoms reporting.

Next, we found differences between boys and girls in the level of self-esteem and in the conflict properties appraisal. In line with previous studies, boys usually report higher self-esteem than girls (e.g., Kling, Hyde, Showers, \& Buswell, 1999). Next, our results showed that girls achieved higher scores in conflict properties than boys, but there was no difference in the level of perceived self-blame and threat in the perception of the interparental conflict. It is possible that girls report more frequent, more intensive and poorly resolved interparental conflicts due to their higher sensitivity to more subtle markers of interpersonal discomfort in the family context. It can be assumed that, through a gender-differentiated way of socializing, a greater focus on the perception of the finer nuances in close interpersonal relationships has been stimulated in girls from an early age (Ruble \& Martin, 1998).

Previous studies have pointed out that family stress may influence the mental health of family members (e.g., Repetti et al., 2002) and that destructive interparental conflicts represent one of the most stressful events in children's lives (Cummings \& Davies, 2002). Our results showed that the higher the level of subjective interparental conflict evaluation, specifically, a higher self-blame for the interparental conflict and a higher perceived threat in the conflict, the higher the level of subjective health complaints. These associations were of small effect sizes and were similar for girls and boys, which is in contrast with our expectations. We hypothesized that because of females' higher sensitiv- 
ity to relationship maintenance and conflict outcomes and consequences, and the males' greater focus on themselves and their own agency (David \& Murphy, 2004; Davies \& Lindsay, 2001; Davies et al., 1999), adolescent girls would be more reactive on interparental conflict than boys. However, our results show that the perceived threat and the feeling of personal responsibility for conflicts between parents are similarly related to subjective health complaints in girls and boys. We can hypothesize that another variable could influence this relationship more than gender itself or in conjunction with gender, e.g. emotional functioning (e.g., David $\&$ Murphy, 2004). For instance, we can hypothesize that girls with low emotional functioning may be more affected by an interparental conflict than boys with low emotional functioning, but girls and boys with high emotional functioning will not differ. Conflict properties such as frequency or intensity are not related to subjective health complaints. It is likely that for subjectively perceived health, the frequency or intensity of conflict is not as important as how much the adolescents feel threatened by the conflict or how much they feel responsible for the cause of conflicts between their parents.

Next, according to our results, the higher the self-esteem, the lower level of self-reported subjective health complaints. Our results are in line with many previous studies that documented the relationship between lower self-esteem and lower physical and psychological health, including somatic complaints, anxiety, depression, etc. (Byrne, 2000; De Jong, Sportel, De Hullu, \& Nauta, 2012). Our results show a significant interaction between sex and self-esteem indicating that self-esteem could play a more important role in subjective health complaints for boys than for girls. Although this result is at the border of statistical significance and therefore must be interpreted with caution, this finding is in line with our expectation. Males are assumed to have more autonomous or individualistic self- schema compared to females and feeling good about themselves is likely more important for them. This could lead to greater relatedness with other aspects of their development including subjective health. Some other authors also suggest that males and females may have different correlates of self-esteem because of different gender socialization (Josephs, Markus, \& Tafarodi, 1992).

Our results offer several possible implications. It is important to point out that destructive interparental conflicts can be considered as a highly distressing factor in adolescence. However, these conflicts are often resistant to interventions. On the other hand, adolescents' selfesteem could be used as an available target of school counselors' interventions.

As for the limitations of our study, it must first be noted that the results ought to be interpreted in light of the fact that the sample was low-risk, i.e. coming from largely intact families. In addition, the rate of families with both biological parents in this study is higher than in the general population in the Czech Republic, in which about $76 \%$ of families with dependent children were complete families and $24 \%$ were incomplete families in 2001 (Český statistický úřad, 2001), and about $78 \%$ of families with dependent children were complete families and 22\% were incomplete families in 2011 (Český statistický úřad, 2011).

Next, the data are more than a decade old, which is one of the limitations of our study. However, is possible to assume that the relationships between the study variables are constant over time, with our results being comparable to older as well as newer studies (e.g., De Jong, Sportel, De Hullu, \& Nauta, 2012; Mechanic \& Hansell, 1989).

Furthermore, the participants in our psychological sub-sample filled out our questionnaires in addition to the required testing in the larger epidemiological study. Therefore, it is reasonable to assume that the sub-sample consists in 
highly motivated families. This further testing can often be stressful for the participating families and consequently, families with high levels of interparental conflict might be underrepresented in the sub-sample due to their unwillingness to undergo further stress. In a similar vein, we are concerned about the effects of filling out the epidemiological paper questionnaires and the duration of the psychological individual testing, therefore, we have to take into account some effect of fatigue.

Given that self-reported measures were used, there is a possibility of social desirability or response style in the answers. However, the current study has the advantage of having the dependent variable of subjective health complaints measured independently from the predictors used, since it was included as a part of the larger epidemiological study. The impact of actual mood or response style on answers in questionnaires would not be so pronounced in timely divided administration. In the case of interparental conflict perception, the use of a self-report questionnaire is relevant for this domain at that age. It has been repeatedly documented that in adolescents, as predictors of outcomes, the accuracy or other objective characteristics of a conflict are not as important as the individual subjective perceptions of the conflict (e.g., Harold, Fincham, Osborne, \& Conger, 1997).

Next, some of the questionnaires were filled out by adolescents at their homes without the direct presence of an administrator. This could be seen both as a benefit and disadvantage. Home administration offers to adolescents more discrete space for answering sensitive questions. On the other hand, we cannot be sure of who filled out the questionnaires.

Despite the aforementioned limitations, this study is to the best of our knowledge the first one to include, besides the perception of a parental conflict, the relationship between selfesteem and the level of subjective health com- plaints in fifteen-year-old Czech adolescents, and to take into account the possible effect of gender. Finally, we must emphasize that this study provides further evidence of the importance of family environment for the well-being in middle adolescence.

\section{References}

Alsaker, F. D., \& Kroger, J. (2006). Self-concept, selfesteem and identity. In J. Jackson \& L. Goossens (Eds.), Handbook of adolescent development (pp. 90-113). New York, NY: Psychology Press.

Amato, P. R., \& Afifi, T. D. (2006). Feeling caught between parents: Adult children's relations with parents and subjective wellbeing. Journal of Marriage and Family, 68(1), 222-235. http://dx.doi.org/ 10.1111/j.1741-3737.2006.00243.x

Aro, H., \& Taipale, V. (1987). The impact of timing of puberty on psychosomatic symptoms among fourteen-to sixteen-year-old Finnish girls. Child Development, 58(1), 261-268. https://doi.org/10.2307/ 1130306

Belmaker, E., Espinoza, R., \& Pogrund, R. (1985). Use of medical services by adolescents with nonspecific somatic symptoms. International Journal of Adolescent Medicine and Health, 1(1-2), 149156 .

Berntsson, L. T., \& Köhler, L. (2001). Long-term illness and psychosomatic complaints in children aged 2-17 years in the five Nordic countries: Comparison between 1984 and 1996. The European Journal of Public Health, 11(1), 35-42. https://doi.org/ 10.1093/eurpub/11.1.35

Brannick, M. T. (1995). Critical comments on applying covariance structure modeling. Journal of Organizational Behavior, 16(3), 201-213. https://doi.org/ 10.1002/job.4030160303

Byrne, B. (2000). Relationship between anxiety, fear, self-esteem, and coping strategies in adolescence. Adolescence, 35(137), 201-216.

Cummings, E. M., \& Davies, P. T. (2002). Effects of marital conflict on children: Recent advances and emerging themes in processoriented research. Journal of Child Psychology and Psychiatry, 43(1), 3163. https://doi.org/10.1111/1469-7610.00003

Český statistický úřad. (2001). Sčítání lidu, domů a bytů. Retrieved from: https://www.czso.cz/csu/sldb/ datove publikace

Český statistický úřad. (2011). Sčitání lidu, domů a bytů. Retrieved from: https://www.czso.cz/csu/sldb

David, K. M., \& Murphy, B. C. (2004). Interparental conflict and late adolescents' sensitization to con- 
flict: The moderating effects of emotional functioning and gender. Journal of Youth and Adolescence, 33(3), 187-200.

Davies, P. T., \& Lindsay, L. L. (2001). Does gender moderate the effects of marital conflict on children? In J. H. Grych \& F. D. Fincham (Eds.), Interparental Conflict and Child Development: Theory, Research, and Application (pp. 64-97). Cambridge University Press, Cambridge, UK.

Davies, P. T., Myers, R. L., Cummings, E. M., \& Heindel, S. (1999). Adult conflict history and children's subsequent responses to conflict: An experimental test. Journal of Family Psychology, 13(4), 610-628.

De Jong, P. J., Sportel, B. E., De Hullu, E., \& Nauta, M. H. (2012). Co-occurrence of social anxiety and depression symptoms in adolescence: Differential links with implicit and explicit self-esteem?. Psychological Medicine, 42(3), 475-484. https://doi.org/ $10.1017 / \mathrm{S} 0033291711001358$

Erol, R. Y., \& Orth, U. (2011). Self-esteem development from age 14 to 30 years: A longitudinal study. Journal of Personality and Social Psychology, 101(3), 607-619. http://dx.doi.org/10.1037/ a0024299

Fink, P., Sørensen, L., Engberg, M., Holm, M., \& Munk-Jørgensen, P. (1999). Somatization in primary care: Prevalence, health care utilization, and general practitioner recognition. Psychosomatics, 40(4), 330-338. https://doi.org/10.1016/S00333182(99)71228-4

Geckova, A., Tuinstra, J., Pudelsky, M., Kovarova, M., van Dijk, J. P., Groothoff, J. W., \& Post, D. (2001). Self-reported health problems of Slovak adolescents. Journal of Adolescence, 24(5), 635646. https://doi.org/10.1006/jado.2001.0422

Ghandour, R. M., Overpeck, M. D., Huang, Z. J., Kogan, M. D., \& Scheidt, P. C. (2004). Headache, stomachache, backache, and morning fatigue among adolescent girls in the United States: Associations with behavioral, sociodemographic, and environmental factors. Archives of Pediatrics \& Adolescent Medicine, 158(8), 797-803. https://doi.org/10.1001/ archpedi.158.8.797

Grych, J. H., Seid, M., \& Fincham, F. D. (1992). Assessing marital conflict from the child's perspective: The Children's Perception of Interparental Conflict Scale. Child Development, 63(3), 558-572. https://doi.org/10.1111/j.1467-8624.1992. tb01646.x

Harold, G. T., Fincham, F. D., Osborne, L. N., \& Conger, R. D. (1997). Mom and dad are at it again: Adolescent perceptions of marital conflict and adolescent psychological distress. Developmental Psychology, 33(2), 333-350.
Haugland, S., Wold, B., Stevenson, J. I. M., Aaroe, L. E., \& Woynarowska, B. (2001). Subjective health complaints in adolescence: A cross-national comparison of prevalence and dimensionality. The European Journal of Public Health, 11(1), 4-10. https:/ /doi.org/10.1093/eurpub/11.1.4

Hetland, J., Torsheim, T., \& Aarø, L. E. (2002). Subjective health complaints in adolescence: Dimensional structure and variation across gender and age. Scandinavian Journal of Public Health, 30(3), 223230. https://doi.org/10.1177/140349480203000309

Chen, F. F. (2007). Sensitivity of goodness of fit indexes to lack of measurement invariance. Structural Equation Modeling, 14(3), 464-504. https://doi.org/ $10.1080 / 10705510701301834$

Inchley, J., Currie, D., Young, T., Samdal, O., Torsheim, T., Augustson, L., ... \& Barnekow, V. (2016). Growing up unequal. HBSC 2016 study (2013/2014 survey). Health policy for children and adolescents, (7). Retrieved from: http://www.euro.who.int/ data/ assets/pdf_file/0003/303438/HSBC-No.7-Growingup-unequal-Full-Report.pdf?ua $=1$

Ježek, S., Lacinová, L., Širůček, J., \& Michalčáková, R. (2008). The psychological branch of the ELSPAC study: A survey of 15-year-old respondents. In S. Ježek \& L. Lacinová (Eds.), Fifteen-year-olds in Brno: A slice of longitudinal self-reports (pp. 711). Brno: Masaryk University.

Jones, G. T., Silman, A. J., Power, C., \& Macfarlane, G. J. (2007). Are common symptoms in childhood associated with chronic widespread body pain in adulthood?: Results from the 1958 British birth cohort study. Arthritis \& Rheumatism, 56(5), 1669-1675. https://doi.org/10.1002/art.22587

Josephs, R. A., Markus, H. R., \& Tafarodi, R. W. (1992). Gender and self-esteem. Journal of Personality and Social Psychology, 63(3), 391-402.

Kinnunen, P., Laukkanen, E., \& Kylmä, J. (2010). Associations between psychosomatic symptoms in adolescence and mental health symptoms in early adulthood. International Journal of Nursing Practice, 16(1), 43-50. https://doi.org/10.1111/j.1440172X.2009.01782.x

Kling, K. C., Hyde, J. S., Showers, C. J., \& Buswell, B. N. (1999). Gender differences in self-esteem: A meta-analysis. Psychological Bulletin, 125(4), 470500. http://dx.doi.org/10.1037/0033-2909.125.4. 470

Lacinová, L., Michalčáková, R., \& Ježek, S. (2009) Škála dětské percepce konfliktu mezi rodiči: Česká verze dotazníku pro adolescenty. Československá Psychologie, 53(1), 70-85.

Låftman, S. B., \& Östberg, V. (2006). The pros and cons of social relations: An analysis of adolescents' health complaints. Social Science \& Medicine, 
63(3), 611-623. https://doi.org/10.1016/j.socscimed. 2006.02 .005

Macek, P., Bouša, O., Vančura, J., Sokoliová, M., \& Neusar, A. (2011). Development of self. In S. Ježek, L. Lacinová, \& P. Macek (Eds.), Adolescent psychosocial development in Brno: An ELSPAC study 2005 - 2011 (pp. 17-32). Brno: Masaryk University.

Mechanic, D., \& Hansell, S. (1989). Divorce, family conflict, and adolescents' well-being. Journal of Health and Social Behavior, 30(1), 105-116. https:/ /doi.org/10.2307/2136916

Michael, K. C., Torres, A., \& Seemann, E. A. (2007). Adolescents' health habits, coping styles and selfconcept are predicted by exposure to interparental conflict. Journal of Divorce \& Remarriage, 48(12), 155-174. https://doi.org/10.1300/J087v48n01_ 09

Osecká, L., \& Blatný, M. (1997). Struktura globálního vztahu k sobě: Analýza Rosenbergovy škály sebehodnocení - replikace. Československá Psychologie, 61(6), 481-486.

Osecká, L., Macek, P., \& Řehulková, O. (1999). Negativní události, konflikty s rodiči a negativn emoce jako prediktory zdravotních stesků adolescentů: Rozdíly mezi dívkami a chlapci. Československá Psychologie, 43(2), 97-104.

Piko, B. F., Varga, S., \& Mellor, D. (2016). Are adolescents with high self-esteem protected from psychosomatic symptomatology? European Journal of Pediatrics, 175(6), 785-792. https://doi.org/10. 1007/s00431-016-2709-7

Piler, P., Kandrnal, V., Kukla, L., Andrýsková, L. Švancara, J., Jarkovský, J., ... \& Klánová, J. (2017). Cohort Profile: The European Longitudinal Study of Pregnancy and Childhood (ELSPAC) in the Czech Republic. International Journal of Epidemiology, 46(5), 1379-1379f. https://doi.org/10.1093/ije/ dyw091

Ravens-Sieberer, U., Torsheim, T., Hetland, J., Vollebergh, W., Cavallo, F., Jericek, H., ... \& Erhart, M. (2009). Subjective health, symptom load and quality of life of children and adolescents in Europe. International Journal of Public Health, 54(2), 151159. https://doi.org/10.1007/s00038-009-5406-8
Repetti, R. L., Taylor, S. E., \& Seeman, T. E. (2002). Risky families: Family social environments and the mental and physical health of offspring. Psychological Bulletin, 128(2), 330-366. http://dx.doi.org/ 10.1037/0033-2909.128.2.330

Robinson, M. D., Mitchell, K. A., Kirkeby, B. S., \& Meier, B. P. (2006). The self as a container: Implications for implicit self-esteem and somatic symptoms. Metaphor and Symbol, 21(3), 147-167. https://doi.org/10.1207/s15327868ms2103_2

Rosenberg, M. (1979). Conceiving the Self. New York: Basic Books.

Roth-Isigkeit, A., Thyen, U., Stöven, H., Schwarzenberger, J., \& Schmucker, P. (2005). Pain among children and adolescents: Restrictions in daily living and triggering factors. Pediatrics, 115(2), e152e162. https://doi.org/10.1542/peds.2004-0682

Ruble, D. N., \& Martin, C. L. (1998). Gender development. In W. Damon \& N. Eisenberg (Eds.), Handbook of child psychology, Vol. 3: Social, emotional, and personality development (pp. 933-1016). New York: Wiley.

Shelton, K. H., \& Harold, G. T. (2007). Marital conflict and children's adjustment: The mediating and moderating role of children's coping strategies. Social Development, 16(3), 497-512. https://doi.org/ 10.1111/j.1467-9507.2007.00400.x

Strandbu, Å., \& Kvalem, I. L. (2014). Body talk and body ideals among adolescent boys and girls: A mixed-gender focus group s tudy. Youth \& Society, 46(5), 623-641. https://doi.org/10.1177/ 0044118 X12445177

Sweeting, H., \& West, P. (2003). Sex differences in health at ages 11, 13 and 15. Social Science \& Medicine, 56(1), 31-39. https://doi.org/10.1016/S02779536(02)00010-2

Takata, Y., \& Sakata, Y. (2004). Development of a Psychosomatic Complaints Scale for Adolescents. Psychiatry and Clinical Neurosciences, 58(1), 3-7. https://doi.org/10.1111/j.1440-1819.2004.01184

Torsheim, T., \& Wold, B. (2001). School-related stress, support, and subjective health complaints among early adolescents: A multilevel approach. Journal of Adolescence, 24(6), 701-713. https://doi.org/ $10.1006 /$ jado. 2001.0440 